Volume 3, Number 2, Agustus 2020

p-ISSN: 2615-0212 | e-ISSN: 2621-2838

https://ejournal.iaifa.ac.id/index.php/dirasah

\begin{tabular}{|c|c|c|}
\hline Accepted: & Revised: & Published: \\
April 2020 & Mei 2020 & Agustus 2020 \\
\hline
\end{tabular}

\title{
Implementasi Metode Cooperative Integrated Reading and Composition (CIRC) untuk Meningkatkan Kemampuan Menulis Puisi Bebas Siswa Kelas V Ilyasa MI Perwanida Kota Blitar
}

\author{
Ika Setiawati \\ STIT Al-Muslihun Blitar, Indonesia \\ Email:ikast@yahoo.com
}

\begin{abstract}
Indonesian language is one of the subjects that is often considered easy by students, but in fact the value of Indonesian language has never occupied the first level in other subjects, especially in writing free poetry material, students often find writing poetry very easy. The fact is that in writing poetry students do not pay attention to the procedures that is good and right. This research are interested in the application of the CIRC method in writing free poetry material. Because this method emphasizes learning to read and write language in high-level classes. In its implementation, it requires planning stages, implementation stages and evaluation stages. In this study using the Classroom Action Research design. Data collection techniques using observation, documentation, and tests. Qualitative data is analyzed by qualitative descriptive analysis while quantitative data is analyzed by quantitative descriptive. From research conducted in the field, the CIRC method of learning to write free poetry by grouping students into groups can improve students' ability to write free poetry at MI Perwanida Blitar City. The results of the application increased significantly from the pretest score of $45 \%$ of 30 students who completed writing free pusi properly and correctly. Then, Cycle I the average value of students obtained was 82 with a student completeness level of $66.6 \%$. Next in cycle II the average value of students is 89 with a level of completeness of students by $95 \%$ of 30 students.
\end{abstract}

Keywords: Problem based learning, creative thinking, social studies 


\begin{abstract}
Abstaksi
Bahasa Indonesia merupakan salah satu mata pelajaran yang sering dianggap mudah oleh para siswa, tetapi sebenarnya nilai mata pelajaran Indonesia tidak pernah menduduki tingkat pertama dibanding mata pelajaran lain. Ketika siswa menganggap mudah pelajaran bahasa Indonesia karena alasan penggunaan sehari-hari, hal itulah yang memicu siswa untuk tidak lagi aktif dalam belajar. Inilah yang kemudian akan membuat nilai pelajaran bahasa Indonesia selalu di bawah mata pelajaran lain. Terutama dalam menulis materi puisi bebas. Agar nilai mata pelajaran Bahasa Indonesia dapat bersaing dengan mata pelajaran lain, peneliti tertarik mengkaji penerapan metode CIRC dalam menulis materi puisi bebas sebagai solusi yang tepat dikarenakan metode ini menekankan belajar membaca dan menulis bahasa di kelas tingkat tinggi. Dalam pelaksanaannya, memerlukan tahapan perencanaan, pelaksanaan dan evaluasi. Penelitian ini menggunakan desain kelas Action Research. Teknik pengumpulan data menggunakan pengamatan, dokumentasi, dan tes. Data kualitatif dianalisis dengan analisis deskriptif kualitatif sementara data kuantitatif dianalisis dengan kuantitatif deskriptif. Dari penelitian yang dilakukan, metode CIRC belajar menulis puisi bebas dengan mengelompokkan siswa dapat meningkatkan kemampuan siswa dalam menulis puisi bebas di MI PerwanidaBlitar City. Hasil aplikasi meningkat secara signifikan dimana Skor Pretest sebesar 45\% dari 30 siswa yang menyelesaikan penulisan puisi bebas dengan benar dan tepat. Selanjutnya, siklus I nilai ratarata siswa yang diperoleh adalah 82 dengan tingkat pencapaian siswa 66,6\%. Selanjutnya dalam siklus II nilai rata-rata siswa adalah 89 dengan tingkat pencapaian siswa $95 \%$.
\end{abstract}

Kata Kunci: Metode CIRC, Bahasa Indonesia, ketrampilan menulis puisi

\title{
Pendahuluan
}

\section{Pembelajaran Bahasa Indonesia di Sekolah Dasar}

Pembelajaran Bahasa Indonesia merupakan pembelajaran yang dirancang untuk menggali prestasi dan pengalaman belajar siswa dalam pembelajaran bahasa Indonesia agar mampu memenuhi pencapaian kompetensi dasar yang telah ditetapkan melalui aspek pengetahuan, sikap, dan keterampilan.Pembelajaran Bahasa Indonesia mempunyai peran yang sangat penting dalam perkembangan siswa baik secara intelektual, sosial, maupun emosional.

Pembelajaran Bahasa Indonesia bukan pembelajaran yang menekankan pada teori saja. Hal ni sejalan dengan pendapat yang menyatakan bahwa

Dirasah, Vol. 3, No.2, Agustus 2020 
"pembelajaran Bahasa Indonesia lebih menekankan pada keterampilan berbahasa dan apresiasi sastra, sehingga pembelajaran Bahasa Indonesia lebih menekankan pada kegiatan berbahasa yang menggunakan empat keterampilan berbahasa yang ada. Keempat keterampilan itu adalah menyimak, berbicara, mambaca, dan menulis. Dalam pelaksanaanya keempat aspek itu tidak bisa berdiri sendiri, akan tetapi selalu terpadu. ${ }^{1}$

Tujuan pembelajaran Bahasa Indonesia diarahkan kepada kemampuan siswa melakukan komunikasi dengan bahasa Indonesia sesuai dengan fungsinya. Pembelajaran Bahasa Indonesia harus diarahkan ke dalam tiga aspek pembelajaran, yaitu: pengetahuan (kognitif), sikap (afektif), dan keterampilan (psikomotorik). Adapun tujuan pembelajaran bahasa Indonesia di Sekolah Dasar berdasarkan Peraturan Menteri Pendidikan Nasional Nomor 22 Tahun 2006 yaitu peserta didik memiliki kemampuan antara lain; (a) berkomunikasi secara efektif dan efisien sesuai dengan etika yang berlaku, baik secara lisan maupun tulis; (b) menghargai dan bangga menggunakan Bahasa Indonesia sebagai bahasa persatuan dan bahasa negara; (c) memahami Bahasa Indonesia dan menggunakannya dengan tepat dan kreatif untuk berbagai tujuan; (d) menggunakan Bahasa Indonesia untuk meningkatkan kemampuan intelektual, serta kematangan emosional dan sosial; (e) menikmati dan memanfaatkan karya sastra untuk memperluas wawasan, memperhalus budi pekerti, serta meningkatkan pengetahuan dan kemampuan berbahasa; dan (f) menghargai dan membanggakan sastra Indonesia sebagai khazanah budaya dan intelektual manusia Indonesia.

Untuk mencapai tujuan di atas, pembelajaran Bahasa berpedoman pada prinsip-prinsip belajar Bahasa yang kemudian diwujudkan dalam kegiatan pembelajarannya. Secara umum prinsip pembelajaran Bahasa Indonesia menurut Hapsoyo yaitu: (a) materi harus sesuai dengan taraf perkembangan siswa, (b) topik sesuai dengan lingkungan, (c) sumber belajar dekat dengan lingkungan, (d) sarana/alat bantu pengajaran mudah diperoleh, dan (e) kegiatan belajar mengajar sesuai dengan kemampuan berkomunikasi dan keterampilan

\footnotetext{
${ }^{1}$ Haryadi dan Zamzami,Peningkatan Keterampilan Berbahsa Indonesia(Jakarta: Depdikbud Dirjen Dikti Bagian Pengembangan Pendidikan Guru Sekolah Dasar, 1997). 3
} 
proses yang dikembangkan. Prinsip-prinsip tersebut menjadi pegangan bagi guru dalam memilih bahan ajar serta menentukan cara dan alat dalam evaluasi. ${ }^{2}$

\section{Hakiakat Menulis}

Menulis dan membaca sebagai aktivitas komunikasi, merupakan kegiatan yang saling melengkapi. White menyebutkan bahwa antara membaca dan menulis terdapat hubungan yang saling menunjang dan melengkapi. Artinya, kebiasaan membaca tidak mungkin terlaksana tanpa kebiasaan menulis atau mengarang, sebaliknya kebiasaan menulis tidak akan bermakna tanpa diikuti oleh kebiasaan membaca. ${ }^{3}$

\section{1. pengertian menulis}

Keterampilan menulis sebagai salah satu cara dari empat keterampilan berbahasa yang mempunyai peranan penting di dalam kehidupan manusia. Dengan menulis, seseorang dapat mengungkapkan pikiran dan gagasan untuk mencapai maksud dan tujuannya. Menulis adalah menurunkan atau melukiskan lambang-lambang grafik menggambarkan suatu bahasa yang dipakai oleh seseorang, sehingga orang-orang lain dapat membaca lambang-lambang grafik tersebut kalau mereka memahami bahasa dari gambaran grafik itu. ${ }^{4}$ Pendapat tersebut menunjukkan bahwa dengan tulisan dapat terjadi komunikasi antara penulis dan pembaca. Hal ini dapat terjadi apabila penulis dan pembaca dapat memahami grafik yang dipergunakan untuk menulis tersebut.

Byrne dalam Haryadi, mengemukakan bahwa mengarang pada hakikatnya bukan sekedar menulis simbol-simbol grafis sehingga berbentuk kata, dan kata-kata disusun menjadi kalimat menurut peraturan tertentu, akan tetapi mengarang adalah menuangkan buah pikiran ke dalam bahasa tulis melalui kalimat-kalimat yang dirangkai secara utuh, lengkap dan jelas sehingga buah pikiran tersebut dapat dikomunikasikan kepada pembaca dengan berhasil. Secara singkat dapat dikatakan bahwa kegiatan

\footnotetext{
${ }^{2}$ SunartoHapsoyo dkk. Readres Bahasa Indonesia 3 (Malang : Departemen Pendidikan dan Kebudayaan, 1993), 6.

${ }^{3}$ Haryadi dan Zamzami, Peningkatan .75.

${ }^{4}$ Henry Guntur Tarigan,Menulis Sebagai Suatu Keterampilan Berbahasa (Bandung: Angkasa, 1986), 21.
} 
mengarang, pengarang menggunakan bahasa tulis untuk menyatakan isi hati dan buah pikirannya secara menarik dan mengena pada pembaca. ${ }^{5}$

\section{Tujuan Menulis}

Tulisan pada dasarnya adalah sarana untuk menyampaikan pendapat atau gagasan agar dapat dipahami dan diterima orang lain. Pembelajaran menulis memiliki tujuan instruksional umum yang termuat dalam GBPP. Tujuan instruksional pengajaran menulis dalam GBPP mengemukakan bahwa tujuan pengajaran menulis memberikan informasi kepada guru bahasa Indonesia tentang pengalaman belajar yang perlu diusahakan bagi siswa dengan penyajian pokok bahasan, subpokok bahasan, atau materi tertentu. $^{6}$

Berdasarkan uraian di atas, menulis mempunyai tujuan untuk melatih siswa agar memiliki kemampuan dalam menulis atau dalam menyampaikan dan menuangkan segala gagasan, pendapat, perasaan, dan pengalamannya ke dalam bentuk tulisan. Dengan keterampilan menulis yang dimiliki siswa dapat mengembangkan kreativitas dan dapat mempergunakan bahasa sebagai sarana menyalurkan kreativitasnya dalam kehidupan sehari-hari dalam bentuk tulisan. Sehingga membentuk interaksi komunikatif antar penulis dan pembaca (misalnya antara guru dan siswa dalam kegiatan pembelajaran menulis). Selain itu, menulis juga bertujuan untuk mengekspresikan diri dan sekaligus untuk merangsang perhatian, minat, dan perasaan, serta mempermudah siswa dalam kegiatan belajar untuk mencapai tujuan pembelajaran.

\section{Proses Menulis}

Proses pembelajaran menulis terdiri dari beberapa tahap yaitu pramenulis, menulis, merevisi, mengedit, dan mempublikasikan. Secara padat proses menulis terdiri dari lima tahap yaitu: (a) pramenulis, merupakan kegiatan pada tahap persiapan yaitu penulis baru menemukan gagasan, menentukan judul karangan, menentukan tujuan, memilih bentuk dan jenis tulisan, membuat karangan, dan mengumpulkan bahan-bahan. (b) menulis, pada tahap ini dimulai dengan menjabarkan ide dalam bentuk

\footnotetext{
${ }^{5}$ Haryadi dan Zamzami, Peningkatan .77

${ }^{6}$ Akhadiah, Sabarti dkk,Bahasa Indonesia I(Jakarta: Depdikbud Dirjen Dikti Proyek Pembinaan Tenaga Kependidikan, 1998). 65.
} 
tulisan. Ide-ide itu dituangkan dalam bentuk kalimat dan paragraf yang kemudian dirangkai menjadi karangan utuh. Pada tahap ini diperlukan berbagai pengetahuan kebahasaan dan teknik penulisan. (c) merevisi, pada tahap ini dilakukan koreksi terhadap keseluruhan karangan yang dilakukan pada berbagai aspek, misalnya struktur karangan dan kebahasaan. (d) mengedit, apabila karangan sudah dianggap sempurna dilakukan tahap pengeditan. Di sini diperlukan format baku yang akan menjadi acuan, misalnya ukuran kertas, bentuk tulisan, dan pengaturan spasi. (e) mempublikasikan, yang berarti menyampaikan karangan pada publik dalam bentuk cetakan atau dalam bentuk non cetak, seperti pementasan, penceritaan, peragaan, dan sebagainya.

Berdasarkan uraian di atas dapat diketahui bahwa proses menulis terdiri dari: tahap pramenulis, tahap menulis, tahap merevisi, tahap mengedit, dan yang terakhir tahap mempublikasikan. ${ }^{7}$

\section{Puisi Bebas}

Puisi adalah karaya sastra yang sangant hemat menggunakan kata-kata. Kekuatannya terletak pada kata-kata yang dipilih dengan prinsip sedikit kata akan tetapi banyak makna. Dengan kata lain, bisa disimpulkan bahwa puisi adalah karangan yang terikat oleh pemilihan diksi, rima, dan suku kata dengan bentuk yang berangkap. ${ }^{8}$

Karakter puisi yang seperti ini mengharuskan penulis atau pengarangnya memeiliki pemikiran yang dalam, dengan sensitifitas persaan yang tinggi. Di samping kedalaman makna, dalam puisi juga terkandung keindahan kata. Dalam masyrakat melayu, konsep keindahan tersebutbiasanya berkaitan dengan unsur kekaguman pada alam, maka yang bersifat oposisi biner (seperti tinggi randah) atau berbagai perasaan menjalani kehidupan. ${ }^{9}$

Sedangkan yang dimaksud dengan puisi bebas ialah puisi yang tidak terikat oleh rima, irama, penyusunan larik, bait, ataupun suku kata. Penulisan dalam sebuah puisi sering kali mengguanakan kata kiasan, Kata kiasan adalah kata yang memiliki bunga-bunga bahasa. Kata tersebut memiliki arti yang bukan sebenarnya. Kata kiasan digunakan untuk menimbulkan keindahan.

\footnotetext{
${ }^{7}$ Haryadi dan Zamzami, Peningkatan Keterampilan . 78.

${ }^{8}$ Sigodang, Pengertian Puisi (blogspot.com diakses tanggal 1 maret 2013)

${ }^{9}$ Ibid.
}

Dirasah, Vol. 3, No.2, Agustus 2020 
Selain itu, digunakan untuk menekankan maksud yang ingin disampaikan. Penggunaan kata kiasan, misalnya, dapat di temukan dalam syair lagu danpuisi. $^{10}$

Ada beberapa hal yang harus difahami saat membuat puisi bebas, ialah : 1) Menenentukan tema, 2) Menentukan judul yang relavan dengan tema, 3) Menentukan pesan yang akan di sampaikan, 4) Membuat kerangka puisi, 5) Memilih diksi yang tepat untuk memperhatikan unsur persajakan, 6) Menggunakan gaya imajinasi, 7) Mangembangkan kerangka puisi menjadi puisi yang indah ${ }^{11}$

Pada saat menulis puisi perlu mengetahui unsur-unsur yang membayangkan sebuah puisi .unsur yang membangun sebuah puisi disebut unsur inrinsik ${ }^{12}$,yang meliputi :

1. Irama dan Rima

Irama,yaitu keselarasan bunyi yang ada pada puisi yang di bentuk oleh pergantian tekanan kata.

rima, yaitu persamaan bunyi yang ada pada baris-baris puisi (sajak).

2. Diksi atau pilihan kata yang tepat .

Diksi, yaitu pilihan kata yang tepat dari penulis (dapat berupa gaya bahasa citraan makna konotasi).

3. Baris dan Bait

Baris dalam bait di gunakan untuk menentukan bentuk puisi.

\section{Pembelajaran Kooperatif}

Pembelajaran kooperatif (Cooperative Learning) merupakan metode pembelajaran yang mengutamakan kerjasama siswa untuk mencapai tujuan pembelajaran. Pembelajaran kooperatif dicirikan oleh struktur tugas, tujuan, dan penghargaan kooperatif. Siswa yang belajar dalam kondisi pembelajaran kooperatif didorong dan dikehendaki untuk bekerjasama pada suatu tugas bersama, dan mereka harus mengkoordinasikan usahanya untuk menyelesaikan tugasnya.

\footnotetext{
${ }^{10}$ Suyatno,dkk. Indahnya Bahasa dan Sastra Indonesia, (Jakarta: Pusat Perbukuan Departemen Pendidikan Nasional, 2008), 137

${ }^{11}$ Murtaqi, Imam. Menulis Puisi Bebas (Wordpress. Com diakses pada tanggal 1 maret)

${ }^{12}$ Ibid
} 
Pembelajaran kooperatif merupakan metode pengajaran di mana siswa belajar dalam kelompok-kelompok kecil yang memiliki tingkat kemampuan berbeda. ${ }^{13}$ Sedangkan menurut Slavin dalam Isjoni, pembelajaran kooperatif adalah suatu metode pembelajaran di mana siswa belajar dan bekerja dalam kelompok-kelompok kecil secara kolaboratif yang anggotanya 4-6 orang dengan struktur kelompok heterogen. ${ }^{14}$

Metode pembelajaran kooperatif dikembangkan untuk mencapai hasil belajar berupa prestasi akademik, toleransi, menerima keragaman, dan pengembangan ketrampilan sosial. Untuk mencapai hasil belajar itu metode pembelajaran kooperatif adanya kerja sama dan interdepensi peserta didik dalam struktur tugas, struktur tujuan, dan struktur reward-nya. Struktur tugas berhubungan bagaimana tugas diorganisir. Struktur tujuan dan reward mengacu pada derajat kerja sama atau kompetisi yang dibutuhkan untuk mencapai tujuan maupun reward. ${ }^{15}$

\section{MetodePembelajaran Cooperative Integrated Reading and Composition (CIRC) Definisi Pembelajaran CIRC}

Metode Pembelajaran kooperatif tipe CIRC termasuk salah satu metode cooperative learning. Metode pembelajaran $C I R C$ merupakan "sebuah program yang komprehansif untuk mengajari pelajaran membaca, menulis, dan seni berbahasa pada kelas yang lebih tinggi di sekolah dasar. Pendapat tersebut menunjukkan bahwa kegiatan pembelajaran yang dilaksanakan pada kelas tinggi (IV-VI) dengan menggunakan metode CIRC meliputi kegiatan membaca, menulis, dan seni berbahasa.

Metode pembelajaran CIRC, siswa ditempatkan dalam kelompokkelompok kecil yang heterogen. Sehingga dalam sebuah kelompok terdapat siswa yang pandai, sedang ataupun lemah, dan masing-masing siswa merasa cocok satu sama lain. Dengan pembelajaran kooperatif diharapkan siswa dapat meningkatkan cara berfikir kritis, kreatif, dan menumbuhkan rasa sosial yang tinggi.

\footnotetext{
${ }^{13}$ Sofan Amri dan Ahmadi Iif Khoiru, Proses Pembelajaran Kreatif dan Inovatif dalam Kelas Metode, Landasan Teori-Praktis dan Penerapannya, (Jakarta: PT. Prestasi Pustakarya, 2010), 66.

${ }^{14}$ Agus Suprijono, Cooperative Learning Teori dan Aplikasi Paikem(Yogyakarta: Pustaka Belajar, 2009), 15.

${ }^{15}$ Ibid., 61
}

Dirasah, Vol. 3, No.2, Agustus 2020 


\section{Komponen-komponen dalam Pembelajaran CIRC}

Metode pembelajaran $C I R C$ menurut Slavin memiliki delapan komponen. Kedelapan komponen tersebut antara lain: (a) teams, yaitu pembentukan kelompok heterogen yang terdiri atas 4 atau 5 siswa; (b) placement test, misalnya diperoleh dari rata-rata nilai ulangan harian sebelumnya atau berdasarkan nilai rapor agar guru mengetahui kelebihan dan kelemahan siswa pada bidang tertentu; (c) student creative, melaksanakan tugas dalam suatu kelompok dengan menciptakan situasi dimana keberhasilan individu ditentukan atau dipengaruhi oleh keberhasilan kelompoknya; (d) team study, yaitu tahapan tindakan belajar yang harus dilaksanakan oleh kelompok dan guru memberikan bantuan kepada kelompok yang membutuhkannya; (e) team scorer and team recognition, yaitu pemberian skor terhadap hasil kerja kelompok dan memberikan kriteria penghargaan terhadap kelompok yang berhasil secara cemerlang dan kelompok yang dipandang kurang berhasil dalam menyelesaikan tugas; (f) teaching group, yakni memberikan materi secara singkat dari guru menjelang pemberian tugas kelompok; (g) facts test, yaitu pelaksanaan test atau ulangan berdasarkan fakta yang diperoleh siswa; dan (h) whole-class units, yaitu pemberian rangkuman materi oleh guru di akhir waktu pembelajaran dengan strategi pemecahan masalah. ${ }^{16}$

\section{Tahap-tahap Pembelajaran CIRC}

Tahap-tahap pembelajaran CIRC menurut Suprijono antara lain:(a) membentuk kelompok yang anggotanya secara heterogen; (b) guru memberikan wacana sesuai dengan topik pembelajaran; (c) siswa bekerja sama untuk menemukan ide pokok dan memberi tanggapan terhadap wacana yang ditulis pada lembar kertas; (d) mempresentasikan hasil kelompok; (e) guru membuat kesimpulan bersama; dan (f) penutup. ${ }^{17}$ Sedangkan menurut Abdul Majid langkah-langkah metode CIRC sebagai berikut: (a) guru membentuk kelompok yang beranggotakan empat sampai enam orang peserta didik; (b) guru meminta peserta didik untuk membaca bacaan/wacana/kliping; (c) peserta didik bekerja sama saling membacakan menemukan ide pokok terhadap materi yang dibaca; (d) guru meminta peserta didik untuk mempresentasikan hasil rangkuman

\footnotetext{
${ }^{16}$ Ibid, 204.

${ }^{17}$ Agus Suprijono, Cooperative Learning .130.
} 
kelompoknya; (e) peserta didik lainnya sebagai audiens yang memiliki hak untuk bertanya dan menjawab pertanyaan yang muncul selama presentasi hasil kerja kelompok; (f) guru bertindak sebagai moderator selama presentasi hasil kerja kelompok dan guru membantu peserta didik menarik kesimpulan.

Untuk membuat perencaan yang baik dan dapat menyelenggarakan proses pembelajaran yang ideal, setiap guru harus mengetahui unsur-unsur perencanaan pembelajaran yang baik, antara lain: mengidentifikasi kebutuhan siswa, tujuan yang hendak dicapai, berbagai strategi dan skenario yang relevan digunakan untuk mencapai tujuan, dan kriteria evaluasi. ${ }^{18}$

\section{Kelebihan dan Kekurangan Metode CIRC}

Kelebihan metode pembelajaran CIRC menurut Slavin antara lain: (a) untuk meningkatkan keterampilan siswa dalam menyelesaikan soal pemecahan masalah; (b) dominasi guru dalam pembelajaran berkurang sehingga pembelajaran terpusat pada siswa; (c) siswa termotivasi pada hasil secara teliti, karena bekerja dalam kelompok; (d) para siswa dapat memahami makna soal dan saling mengecek pekerjaannya; (e) membantu siswa yang lemah; (f) meningkatkan hasil belajar khususnya dalam menyelesaikan soal yang berbentuk pemecahan masalah; $(\mathrm{g})$ siswa dapat memberikan tanggapan secara bebas; dan (h) dilatih untuk bekerjasama dan menghargai pendapat orang lain.

Kekurangan metode pembelajaran CIRC adalah pada saat dilakukan presentasi terjadi kecenderungan hanya siswa pandai yang secara aktif tampil menyampaikan pendapat dan gagasan sedangkan siswa yang kurang pandai cenderung diam.

\section{Metode Penelitian}

\section{Pendekatan dan Jenis Penelitian}

Pendekatan yang digunakan dalam penelitian ini adalah pendekatan kualitatif dengan jenis penelitian yang digunakan adalah penelitian tindakan kelas. Penelitian tindakan kelas adalah suatu pencermatan kegiatan belajar berupa sebuah tindakan, yang sengaja dimunculkan dan terjadi dalam sebuah kelas secara bersama. ${ }^{19}$

\footnotetext{
18 Abdul Majid, Perencanaan Pembelajaran Mengembangkan Standar Kompetensi guru, (Bandung: Rosda Karya, 2008), 94.

${ }^{19}$ SuharsimiArikunto, Penelitian Tindakan Kelas, (Jakarta: Bumi Aksara, 2007), 3.
}

Dirasah, Vol. 3, No.2, Agustus 2020 
Dalam penelitian tindakan kelas ini, peneliti melaksanakan melalui dua siklus yaitu siklu I dan siklus II. Dalam mendesain PTK langkah-langkah yang harus dilaksanakan adalah sebagai berikut: ${ }^{20}$ (1) perencanaan (2) implementasi (3) pengamatan (4) refleksi.

Berikut adalah deskripsi dari ke empat kegiatan yang dilakukan pada setiap siklus penelitian

\section{Perencanaan}

Pada tahap tindakan perencanaan ini, peneliti merancang pelaksanaan tindakan yang akan diterapkan. Perencanaan tindakan tersebut antara lain adalah bersama-sama dengan guru kelas V Ilyasa melakukan identifikasi masalah-masalah pembelajaran. Peneliti melakukan observasi kelas, melakukan wawancara dengan guru kelas, kemudian melakukan diskusi untuk mengatasi masalah yang akan diselesaikan melalui PTK. Setelah menemukan permasalahan kemudian menyusun Rencana Pelaksanaan Pembelajaran (RPP) dengan menggunakan metode $C I R C$, menyiapkan media pembelajaran yang terkait dengan materi, mengembangkan media pembelajaran, dan menyusun instrumen penilaian pembelajaran.

2. Pelaksanaan

Pada tahap pelaksanaan tindakan yaitu melaksanakan rencana pembelajaran yang telah disiapkan oleh peneliti dan guru kelas V Ilyasa. Dalam penelitian ini peneliti bertindak sebagi guru sekaligus observer. Pelaksanaan rencana pembelajaran dilakukan sesuai dengan tahapan yang ada dalam RPP.

3. Pengamatan

Tindakan pengamatan ini dilaksanakan bersamaan dengan pelaksanaan tindakan. Pada tahap observasi yaitu melakukan pengamatan dan pencatatan terhadap pelaksanaan dan hasil tindakan yang dilakukan dari awal hingga akhir selama pelaksanaan tindakan yang dilakukan. Sasaran yang perlu diamati dalam kegiatan ini adalah peristiwa-peristiwa yang menjadi indikator keberhasilan atau ketidakberhasilan sebagaimana yang telah tertuang dalam perencanaan diatas.

4. Refleksi

${ }^{20}$ Wahid murni dan Nur Ali, Penelitian Tindakan Kelas Pendidikan Agama dan Umum Dari Teori Menuju Praktik, (Malang:UM PRESS, 2008), 50.

Dirasah, Vol.3, No. 2, Agustus 2020 
Dalam kegiatan refleksi ini peneliti melakukan sebuah diskusi dengan beberapa siswa. Yang perlu didiskusikan dalam kegiatan ini adalah (a) kekurangan yang terjadi selama proses pembelajaran (b) kemajauan yang telah dicapai oleh siswa (c) perencanaan tindakan untuk kegiatan berikutnya. Sedangkan hal-hal yang perlu didiskusikan antara guru dengan peneliti adalah mencakup: (a) kesesuaian antara perencanaan dengan pelaksanaan kegiatan (b) kekurangan yang terdapat selama proses pembelajaran (c) kemajuan yang telah dicapai siswa (d) rencana tindakan pembelajaran selanjutnya.

\section{Prosedur pengumpulan data}

Penelitian yang dilaksanakan di kelas V Ilyasa MI Perwanida ini menggunakan beberapa caraunuk mengumpulkan data dalam proses penelitian berlangsung, diantaranya:

1. Metode Observasi

Yaitu penelitian penelitian yang dilakukan dengan cara pengamatan terhadap obyek tidak mengetahui bahwa dirinya sedang diteliti.

2. Pendekatan partisipatif

Pendekatan ini digunakan untuk lebih menjadikan suasana dalam kegiatan belajar megajar lebih hidup, sehingga peneliti terlibat secara langsung atau berpartisipasi dalam hal pengumpulan yang diinginkan data terkadang pula mengarahkan tindakan atau arahan kepada data yang diinginkan oleh peneliti

3. Tes

Tes yang dilakukan memiliki tujuan untuk mengetahui kemampuan siswa menulis puisi bebas. Tes yang akan dilakukan meliputi:

a. Penilaian proses

Pada penilaian ini yang ditekankan ialah kekompokan siswa dalam mengerjakan tugasnya. Aspek yang mejadi dasar penilaian proses ini meliputi: kerjasama, kemandirian serta tanggung jawab terhada kelompoknya. Keternagan dari aspek penilaian proses:

1) Kerjasamameliputi Kompak untuk menyeleseikan tugas, tanpa bertanya kelompok lain; Melibatkan seluruh anggota kelompok dan Tidak ada dominasi dalam kelompok, memecahkan soal bersama kelompoknya 
2) Kemandirian meliputi kemampuan memberikan argumentasi dan memberikan kritik; kemampuan menggunakan bahasa yang baik dan lancar dalam berbicara dan berani tampil ke depan

3) Tanggung jawab meliputi mengumpulkan tugas tepat waktu; Semua tugas dikerjakan dan bekerja sesuai dengan tugas masing-masing

b. Nilai Hasil

Nilai hasil ini didapat dari ketepatan jawaban siswa dalam menjawab soal secara indifidu yang kemudian dijumlahkan.

c. Nilai Akhir

Nilai akhir dapat diketahui dengan menjumlahkan nilai proses dan nilai hasil kemudian dibagi dua.

Sedangkan untuk mengetahui presentae siswa yang tuntas belajar sebagai berikut:

Keterangan:

$\mathrm{P}=\frac{n}{N} \times 100 \%$

$\mathrm{P}=$ Presentase siswa yang tuntas belejar

$\mathrm{n}=$ banyak siswa yang tuntas belajar

$\mathrm{N}$ = banyak siswa keseluruhan

4. Interview

Wawancara adalah sebuah dialog yang dilakukan oleh pewawancara untuk memperoleh informasi dari terwawancara. ${ }^{21}$ Wawamcara (Interview) dilakukan untuk mendapat masukan dari siswa mengenai pembalajaran yang diberikan sebelumnya. Apakah mereka mengalami kesulitan dalam memahami materi pelajaran dan kesulitan dalam mengerkajan tes

\section{Analisis Data}

\footnotetext{
${ }^{21}$ Suharsini, Arikunto. Prosedur Penelitian Suatu Pendekatan Praktek. (Jakarta: Rineke Cipta, 2002), 132.
} 
Analisis data adalah proses mengorganisasikan dan mengurutkan data ke dalam pola, kategori, dan satuan uraian dasar, sehingga dapat ditemukan tema dan dapat dirumuskan hipotesis kerja. ${ }^{22}$

Analisis data dilakukan setelah pelaksanaan tindakan pada tiap siklus. Analisis data merupakan proses menyeleksi, menyederhanakan, memfokuskan, dan mengorganisasi data secara sistematis dan rasional untuk menyusun jawaban terhadap tujuan penelitian. Teknik analisis data yang digunakan dalam penelitian ini adalah teknik analisis data kualitatif.

Langkah-langkah analisis data kualitatif model Miles and Huberman, sebagai berikut: (1) Reduksi data, (2) Display/penyajian data, (3) Mengambil kesimpulan lalu diverivikasi.

\section{Hasil Penelitian}

Pelaksanaan Metode Cooperative Integrated Reading and Composition (CIRC) untuk Meningkatkan Keterampilan Menulis Puisi Bebas pada Kelas V Ilyasa di MI PerwanidaBlitar.

Penerapan pembelajaran kooperatif dengan metode $C I R C$ bertujuan untuk menumbuhkan semangat belajar siswa yang memungkinkan siswa dapat belajar dengan efektif dan efisien sehingga apabila siswa dapat belajar dengan efektif dan efisien secara otomatis akan mempengaruhi hasil belajar siswa dan tentunya tercapainya tujuan-tujuan dari kegiatan pembelajaran.

Paparan data yang telah disampaikan dengan terlebih dahulu melaksanakan kegitan pretest dapat diketehui bahwa kegiatan pemahaman dan keterampilan dalam menulis terlebih pada menulis puisi bebas masih dirasa sangat sulit bagi mereka hal tersebut dapat terlihat dari kegiatan penelitian di kelas V MI perwanidaBlitar yang dilakukan sebanyak 2 siklus dengan metode CIRC. Pada hasil pretest dapat diketahui bahwasannya hanya 30\% siswa yang mampu mengungkapkan keindahan sebuah benda dalam bentuk puisi bebsa. Pada penelitian ini dilakukan dengan 2 siklus yaitu siklus I dan II dilaksanakan dua kali pertemuan. Pada pertemuan I menggunakan media gambar dan siklus II dengan media teks bacaan dengan cara berkelompok. Pada siklus I dan II terlebih dahulu peneliti menyajikan sebuah tindakan dalam pentuk perencanaan yang mana sudah tertuang dalam bentuk RPP yang peniliti buat sebelumnya,

\footnotetext{
${ }^{22}$ M.Iqbal Hasan, Pokok-Pokok Metodologi penelitian dan Aplikasi (Jakarta: Ghalia Indonesia, 2002), 98.
}

Dirasah, Vol. 3, No.2, Agustus 2020 
kemudian pelaksanaan yaitu eksekusi peneliti dengan membuat kelompok kerja dan membagikan media gambar pada peserta didik. Yang selanjutnya yaitu observasi hal ini untuk memantau sejauh mana peserta didik dapat berkomunikasi dengan kelompok kerjanya dalam memngembangkan imajinasinya dalam membuat puisi bebas secara mandiri. Selanjutnya adalah refleksi yaitu mengukur sejauh mana keberhasilan yang dilakukan oleh peneliti tersebut.

\section{Siklus I pertemuan I dan II}

Dari hasil pelaksanaan tindakan siklus I dapat diketahui bahwa keberhasilan belajar dipresentasikan sebesar $66.6 \%$ dari pelaksanaan siklus I pertemuan I dan II.

Hasil observasi yang dilakukan pada siklus 1 menggambarkan adanya beberapa kendala dalam penggunaan metode, adapun kendalanya :

1. Siswa masih belum sadar bahwa ketika ia berkelompok guru akan meberikan nilai

2. Masih tampak siswa yang paling menonjol pada kelompok sehingga mereka lebih mengerjakan secara indifidu.

3. Penilaian siswa pada penulisan puisi bebas sudah bagus akan tetapi masih ada beberapa siswa yang masih belum bisa membedakan penulisan puisi bebas dan prosa.

Indikator pencapaian pada siklus I pertemuan I dan II adalah :

1. Menentukan ide tulisan dalam bentuk puisi berdasarkan pengalaman atau imajinasi

2. Membuat puisi bebas dengan menggunakan media gambar. Siswa nantinya akan mengembangkan imajinasinya setelah dia memahmi gambar yang telah disajikan.

Hasil observasi yang dilakukan pada siklus 1 menggambarkan adanya beberapa kendala dalam penggunaan metode, adapun kendalanya :

1. Siswa masih belum sadar bahwa ketika ia berkelompok guru akan meberikan nilai

2. Masih tampak siswa yang paling menonjol pada kelompok sehingga mereka lebih mengerjakan secara indifidu. 
3. Penilaian siswa pada penulisan puisi bebas sudah bagus akan tetapi masih ada beberapa siswa yang masih belum bisa membedakan penulisan puisi bebas dan prosa.

Selanjutnya peneliti mengadakan revisi sebagai usaha untuk menghindari kendala di atas. Berdasarka uraian diatas dapat disimpulkan bahwa pelaksanaan tindakan pada siklus I belum berhasil secara menyeluruh baik penilaian hasil dan proses. Akan tetapi pada nilai akhir siswa sudah banyak tuntas sesuai dengan KKM. Selanjutnya peneliti melanjtkan pada siklus II, hal ini bertujuan untuk meningkatkan lagi nilai menulis puisi bebas bagi siswa yang memerlukan perbaikan.

\section{Siklus II pertemuan I dan II}

Dari hasil pelaksanaan tindakan siklus II dapat diketahui bahwa keberhasilan belajar siswa dipresentasikan mencapai 95\% dan pada siklus I yaitu $66.6 \%$. Hal ini meningkat jauh dari mulai kegiatan pretest samapi pada siklus II. Adapun indikator keberhasilan penerapan metode CIRC adalah sebagai berikut:

1. Pada saat pembelajaran berlangsung, siswa terlihat senang dan tidak bosan

2. Dengan metode CIRC siswa terlihat aktif dan asik dengan kelompoknya

3. Dengan metode CIRC siswa dapat memecahkan masalah yang dihadapi dengan kelompoknya

4. Ada peningkatan kemampuan menulis puisi bebas

5. Antara nilai proses dan nilai hasil sama-sama tuntas

Adapun indikator pencapaian pada pertemuan ini adalah :

1. Menentukan ide tulisan dalam bentuk puisi berdasarkan pengalaman atau imajinasi

2. Membuat puisi bebas dengan menggunakan media teks bacaan

Pelajaran pada siklus II ini dilakukan sama ketika mengawali siklus I. Pada siklus II ini guru memberikan umpan balik pada siswa kendala apa yang dialami pada pelaksanaan siklus I. Kemudian guru bersama siswa mencari solusi bersama dengan tujuan pelaksanaan siklus II nantinya dapat mencapai hasil yang maksimal.

Dari pengamatan peneliti melihat antusias siswa membuat puisi sebelumnya sehingga kiranya siswa dapat membedakan penulisan puisi dengan penulisan prosa. Selain itu pada siklus II ini siswa juga diminta mengerjakan 
soal-soal terkait dengan materi yang dipelajari dengan close book. Hal ini dilakukan unutk mengukur kemampuan siswa menerima matrei yang telah disampaikan oleh peneliti. Ketika siswa diminta oleh guru membuat prosa dari puisi yang telah mereka buat sebelumnya dan mengerjakan soal, tidak ada siswa yang bicara sendiri, siswa terlihat fokus pada tugas, tidak ada yang malasmalasan bahkan mengantuk. Semua siswa siswa terlihat begitu antusias dan menikmati pembelajaran yang sedang berlangsung.

\section{Pembahasan}

Fokus penelitan ini dilakukan pada siswa kelas V Ilyasa MI Perwanida Kota Blitar pada pembelajaran Bahasa Indonesia tentang menulis Puisi bebas. Penelitian ini di lakukan 4 kali tatap muka. yang membedakan pada siklus I dan siklus II adalah obyek yang menjadi pokok menulis puisi.

Berdasarakan data empiris dan hasil pengamatan, bahwa untuk meningkatkan kemampuan belajar siswa membutuhkan lingkungan belajar yang kondusif serta metode pembelajaran sesuai dengan materi pelajaran yang sedang diajarkan. Dengan materi pembelajaran yang membuat siswa aktif, tidak jenuh, tidak mengantuk serta lebih bersemangat dalam mengikuti pembelajaran yang berlangsung serta dapat menjadadikan siswa lebih berfikir secara ilmiah. Salah satu cara menciptakan lingkungan belajar yang menyenangkan dan tidak bosan dalam pembelajaran bahasa indonesia adalah dengan menerapkan metode CIRC. Di mana metode ini diharapkan dapat menjadikan siswa lebih meningkatkan kemampuan menulis puisi bebas. Dengan metode CIRC di harapkan juga siswa dapat aktif mengikuti pembelajaran di kelas hal ini dimaksudkan untuk mengoptimalkan peggunaan potensi yang dimiliki siswa, sehingga siswa memperoleh hasil belajar yang memuaskan sesuai karakteristik pribadi yang mereka miliki. ${ }^{23}$

Hasil observasi yang dilakukan peneliti di lapangan menunjukkan adanya peningkatan kemampuan siswa menulis puisi bebas dari kedua siklus ini yang bisa dikatakan maksimal dengan peningkatan hasil yang signifikan pada setiap siklusnya

\section{Penutup}

${ }^{23}$ Hartono. Strategi Active Learning. (www. Edu-articles.com. diakses tanggal 27 Februari 2013) 
Langkah awal perencaaan tindakan ini adalah menganalisis komponen dan isi butir, menetapkan materi pembelajaran, menelaah buku paket bahasa Indonesia kelas $\mathrm{V}$, mengembangkan silabus, menyusun rencana pelaksaan pembelajaran, membuat lembar kegiatan siswa, menyusun instrumen pengumpulan data yang meliputi instrumen observasi untuk mengamati proses siswa dalam pelaksaanpembelajaraan, instrumen lembar observasi untuk mengamati nilai hasil siswa dalam melakukan aktifitas belajar serta instrumen soal ulangan harian.

Proses pelaksanaan pembelajaran Bahasa Indonesia dengan menggunakan metode CIRCsebagai upaya meningkatkan hasil belajar siswa kelas V ilyasa di MI Perwanida Kota Blitar sesuai dengan rencana yang telah disusun. Pada siklus I peneliti berhasil menyampaiakn materi menulis puisi bebas dengan menggunakan media gamabar serta mengubah puisi tersebut menjadi sebuah prosa. Peneliti juga menjelaskan kompetensi dasar yang harus dikuasai, melakukan KBM sesuai RPP dan kemudian peneliti melakukan post tes untuk mengevaluasi pemahaman siswa. Pada siklus ke 2 peneliti meminta siswa menulis puisi bebas dengan menggunakan media teks bacaan dengan terlebih dahulu menentukan ide pokok teks. dan mengadakan post tes.

Proses evaluasi pembelajaran bahasa Indonesia dengan menggunakan metode CIRCsebagai upaya meningkatkan hasil belajar siswa kelas V Ilyasa MI Perwanida Kota Blitar dilaksanakan dengan cara melakukan pengamatan untuk memberikan penilaian dari aktivitas siswa dalam proses pembelajaran, kerjasama masing-masing siswa dalam kelompok selama proses pembelajaran. Proses evaluasi dilakukan pada tiap pertemuan setelah proses pembelajaran berlangsung untuk menentukan sudah sejauh mana pengembangan metode yang sedang dikembangkan telah berhasil sesuai dengan yang direncanakan.

\section{Daftar Pustaka}

Akhadiah, Sabarti dkk. Bahasa Indonesia I . Jakarta: Depdikbud Dirjen Dikti Proyek Pembinaan Tenaga Kependidikan. 1998.

Arikunto, Suharsimi. Penelitian Tindakan Kelas. Jakarta: Bumi Aksara, 2007.

Arikunto, Suharsini. Prosedur Penelitian Suatu Pendekatan Praktek. Jakarta: Rineke Cipta. 2002. 
Depdiknas. BNSP Standar Isi. Jakarta: Depdiknas. 2006.

Hapsoyo, Sunarto dkk. Readres Bahasa Indonesia 3. Malang : Departemen Pendidikan dan Kebudayaan. 1993.

Hartono. Strategi Active Learning. Diakses www. Edu-articles.com. diakses tanggal 27 Februari 2013

Haryadi dan Zamzami. Peningkatan Keterampilan Berbahsa Indonesia Jakarta: Depdikbud Dirjen Dikti Bagian Pengembangan Pendidikan Guru Sekolah Dasar. 1997

Hasan, M.Iqbal. Pokok-Pokok Metodologi penelitian dan Aplikasi. Jakarta: Ghalia Indonesia. 2002.

Majid, Abdul. Perencanaan Pembelajaran Mengembangkan Standar Kompetensi guru. Bandung: Rosda Karya. 2008.

Murtaqi, Imam. Menulis Puisi Bebas. Diakses Wordpress. Com diakses pada tanggal 1 maret 2013

Muslih, Masnur. Melaksanakan PTK itu Mudah Calassroom Action Research, Jakarta: Bumi Aksara. 2009

Sigodang. Pengertian Puisi. Diakses blogspot.com diakses tanggal 1 maret 2013

Sofan Amri dan Ahmadi Iif Khoiru. Proses Pembelajaran Kreatif dan Inovatif dalam Kelas Metode, Landasan Teori-Praktis dan Penerapannya. Jakarta: PT. Prestasi Pustakarya. 2010

Suprijono,Agus. Cooperative Learning Teori dan Aplikasi Paikem. Yogyakarta: Pustaka Belajar. 2009

Suyatno,dkk. Indahnya Bahasa dan Sastra Indonesia. Jakarta: Pusat Perbukuan Departemen Pendidikan Nasional. 2008

Tarigan,Henry Guntur. Menulis Sebagai Suatu Keterampilan Berbahasa (Bandung: Angkasa.1986

Wahid murni dan Nur Ali. Penelitian Tindakan Kelas Pendidikan Agama dan Umum Dari Teori Menuju Praktik. Malang: UM PRESS. 2008 
Copyright (C) 2020Journal Dirasah: Vol. 3, No.2,Agustus 2020, p-ISSN: 2615-0212, e-ISSN; 2621-2838

Copyright rests with the authors

Copyright of Jurnal Dirasah is the property of Jurnal Dirasah and its content may not be copied oremailed to multiple sites or posted to a listserv without the copyright holder's express writtenpermission. However, users may print, download, or email articles for individual use. https://ejournal.iaifa.ac.id/index.php/dirasah 